\title{
Mercury in Forage Fish from Mexico and Central America: Implications for Fish-Eating Birds
}

\author{
John E. Elliott ${ }^{1,6} \cdot$ David A. Kirk $^{2} \cdot$ Kyle H. Elliott ${ }^{3} \cdot$ Jessica Dorzinsky $^{4}$ • \\ Sandi Lee ${ }^{1} \cdot$ Ernesto Ruelas Inzunza $^{5} \cdot$ Kimberly M. T. Cheng $^{6} \cdot$ Tony Scheuhammer ${ }^{4}$. \\ Patrick Shaw ${ }^{7}$
}

Received: 16 December 2014/ Accepted: 22 June 2015

(C) Her Majesty the Queen in Right of Canada as represented by: John Elliott 2015

\begin{abstract}
Mercury (Hg) is a global contaminant of aquatic food chains. Aquatic birds, such as the osprey (Pandion haliaetus), with migratory populations breeding in Canada and the northern United States and wintering in the Central and South America, can be exposed to mercury on both the breeding and wintering ranges. We examined $\mathrm{Hg}$ levels in 14 fish taxa from 24 osprey wintering sites identified from satellite telemetry. Our main goal was to determine whether fish species that feature in the diet of overwintering and resident fish-eating birds reached toxicity thresholds for $\mathrm{Hg}$. Mean $\mathrm{Hg}$ levels in fish whole carcasses ranged from a high of $0.18 \mu \mathrm{g} \mathrm{g}^{-1}$ (wet weight) in
\end{abstract}

Electronic supplementary material The online version of this article (doi:10.1007/s00244-015-0188-x) contains supplementary material, which is available to authorized users.

John E. Elliott

john.elliott@ec.gc.ca

1 Environment Canada, Science and Technology Branch, Pacific Wildlife Research Centre, 5421 Robertson Road RR\# 1, Delta, BC V4K3N2, Canada

2 Aquila Conservation \& Environment Consulting, 75 Albert Street, Suite 300, Ottawa, ON K1P 5E7, Canada

3 McGill University, Sainte-Anne de Bellevue, PQ H9X 3V9, Canada

4 Environment Canada, Science and Technology Branch, National Wildlife Research Centre, Ottawa, ON K1A 0H3, Canada

5 Universidad Veracruzana, Xalapa, Veracruz 91090, Mexico

6 Applied Animal Biology, University of British Columbia, Vancouver, BC, Canada

7 Environment Canada, Science and Technology Branch, 201-401 Burrard Street, Vancouver, BC V6C 3S5, Canada
Scomberomorus sierra to a low of $0.009 \mu \mathrm{g} \mathrm{g}^{-1}$ in Catostomidae. Average $\mathrm{Hg}$ levels were within published toxicity threshold values in forage fish for only two sites in Mexico (Puerto Vallarta and San Blas Estuary), and all were marine species, such as mackerel (Scomberomorus sierra), sea catfish (Ariopus spp.), and sardinas species (Centropomus spp.). Except for one sample from Nicaragua, sea catfish from Puerto Morazan, none of the fish from sites in Central America had $\mathrm{Hg}$ levels which exceeded the thresholds. Nonmetric multidimensional scaling revealed geographical differences in $\mathrm{Hg}$ levels with significant pairwise differences between sites along the Pacific Ocean (Mexico) versus the Bay of Campeche, partly due to differences in species composition of sampled fish (and species distributions). $\mathrm{Hg}$ increased with trophic level, as assessed by nitrogen stable isotope ratios $\left(\delta^{15} \mathrm{~N}\right.$ but not $\delta^{13} \mathrm{C}$ ), in freshwater and marine, but not estuarine, environments. $\mathrm{Hg}$ concentrations in forage fish do not account for the elevated $\mathrm{Hg}$ reported for many osprey populations on the breeding grounds, thus primary sources of contamination appear to be in the north.

Migratory behaviour can be an important factor in determining contaminant exposure in a bird population. Among the species of most concern are piscivores, such as the osprey (Pandion haliaetus), which are at the apex of aquatic food chains and represent important and charismatic indicators for toxic chemicals (Elliott et al. 2007; Grove et al. 2009). The aquatic ecosystems where these species forage are sinks for persistent contaminants from both local and distant sources (Wang et al. 2004). One of these is the global contaminant mercury (Hg) and its highly toxic biological form, methylmercury $(\mathrm{MeHg})$, which has both natural and anthropogenic 
sources and biomagnifies in aquatic systems (EaglesSmith et al. 2009). MeHg can have significant effects on a variety of biological functions and potentially impact both reproduction and survival of wildlife (Wiener et al. 2003; Scheuhammer et al. 2007, 2008, 2012; Dietz et al. 2013).

Major industrial point sources of $\mathrm{Hg}$ have been curtailed largely. Currently, $\mathrm{Hg}$ is released and distributed primarily from low-level atmospheric combustion activities and can be transported to remote environments, including Arctic and alpine systems (Schuster et al. 2002; Wang et al. 2004; Scheuhammer et al. 2007; Guigueno et al. 2012). For example, mercury levels in arctic species, including toothed whales, polar bears (Ursus maritimus), and various bird and fish species were reported often to exceed putative toxicity thresholds (Dietz et al. 2013). Given that $\mathrm{Hg}$ emissions are predicted to continue to increase until at least 2050 (Streets et al. 2009), although this may be attenuated by the global impact of the Minimata Convention on Mercury, it is important to continue to identify sources of $\mathrm{Hg}$ in the food chain and monitor indicator species.

Compared with northern breeding sites, relatively little is known about contaminant exposure in the overwintering areas of many migratory species, such as the Osprey Pandion halieatus (Elliott et al. 1998, 2000, 2007, 2012). Similarly, compared with the extensive data base on $\mathrm{Hg}$ in fish, largely collected as part of game fish monitoring in the United States and Canada (Kamman et al. 2005; Davis et al. 2008; Wyn et al. 2010), there is much less from wintering areas in Mexico and Central America, with some exceptions (Mol et al. 2001; RuelasInzunza and Páez-Osuna 2005). We targeted sampling sites based on our knowledge of where satellite tagged osprey were wintering and some information collected by local biologists on forage fish species preyed upon by ospreys (Elliott et al. 2007). We examined interspecific differences in $\mathrm{Hg}$ concentrations and the toxicological implications of those findings for apex piscivores. We also compared $\mathrm{Hg}$ levels among different geographic regions to test for spatial patterns. Finally, we modelled relationships between $\mathrm{Hg}$ levels and two stable isotopes of carbon $\left(\delta^{13} \mathrm{C}\right.$ and $\left.\delta^{15} \mathrm{~N}\right)$. Those stable isotopes have been used to relate the activities of piscivorous species and $\mathrm{Hg}$ contamination, as well as trace pathways and sources of $\mathrm{Hg}$ in aquatic ecosystems (Choy et al. 2010; Braune et al. 2013). Generally, sources of carbon $\left(\delta^{13} \mathrm{C}\right)$ can be used to examine the relationship between contaminant concentrations and foraging area, because marine sources are more enriched than freshwater ones; sources of nitrogen $\left(\delta^{15} \mathrm{~N}\right)$ are used to indicate trophic level (Post 2002).

\section{Materials and Methods}

\section{Study Areas}

Between 2000 and 2003, fish were sampled from 18 sites in Mexico, including 2 from the state of Jalisco, 3 from Nayarit, 2 from Oaxaca, 2 from Tabasco, and 8 from Veracruz (Fig. 1a, b). In 2007, samples were obtained from five locations in Nicaragua and three in Costa Rica, also as close as possible to known osprey wintering sites (Elliott et al. 2007; Martell et al. 2001, 2014). We worked with local biologists, subsistence fisherman, small commercial fishing operations, and occasionally anglers to collect several fish species that are potential prey of Osprey, including mojarra (Gerridae spp.), catfish (Ariusspp., Rhamdia spp.), guavina (Gobiomurus dormitor), mackerel (Scomberomorus sierra), mullet (Mugil spp.), snook (Centropomidae spp.), surgeonfish (Acanthuridae spp.), and tilapia (Cichlasoma uropthalmus, Oreochromis niloticus). We attempted to collect fish from areas where satellite-tagged Ospreys were wintering or from known Osprey wintering sites in Mexico, including the Laguna de Alvarado in Veracruz State, Villahermosa in Tabasco State, Barra de Navidad in Jalisco State, and the San Blas estuary in Nayarit State (Elliott et al. 2007). To sample a larger geographic area, we collected several samples from small commercial fisherman at dockside or in local markets in other Mexican states and some locations in Central America. A minimum of three to five individual fish of approximately the same length for the same species at each site was used to make up a single composite pool. All samples were labeled and stored in polyethylene bags on ice until frozen locally. Frozen samples were transported by air in coolers on ice to Canada in the accompanying baggage of two of the authors (JEE and/or KEE). All samples were stored at $-20{ }^{\circ} \mathrm{C}$ at the Pacific Wildlife Research Centre, Delta, BC. Each fish sample was partially thawed, weighed, measured, and dissected at the Pacific Environmental Science Centre (PESC) in North Vancouver, British Columbia, Canada to separate the muscle fillets from the remaining carcass. Muscle fillets and composite samples of the remaining carcasses were weighed and analyzed separately according to protocols previously established to assess risk to human consumers of only muscle tissue as well as wildlife that consume whole carcasses.

\section{Mercury Analysis}

Frozen fish samples were shipped on dry ice to the Environment Canada laboratory at the National Wildlife Research Centre (NWRC) in Ottawa, Canada. All muscle tissue analyses were conducted by staff at the NWRC 
Fig. 1 Locations where forage fish samples were collected in: a Mexico, 2000-2003 and b Nicaragua and Costa Rica, 2007

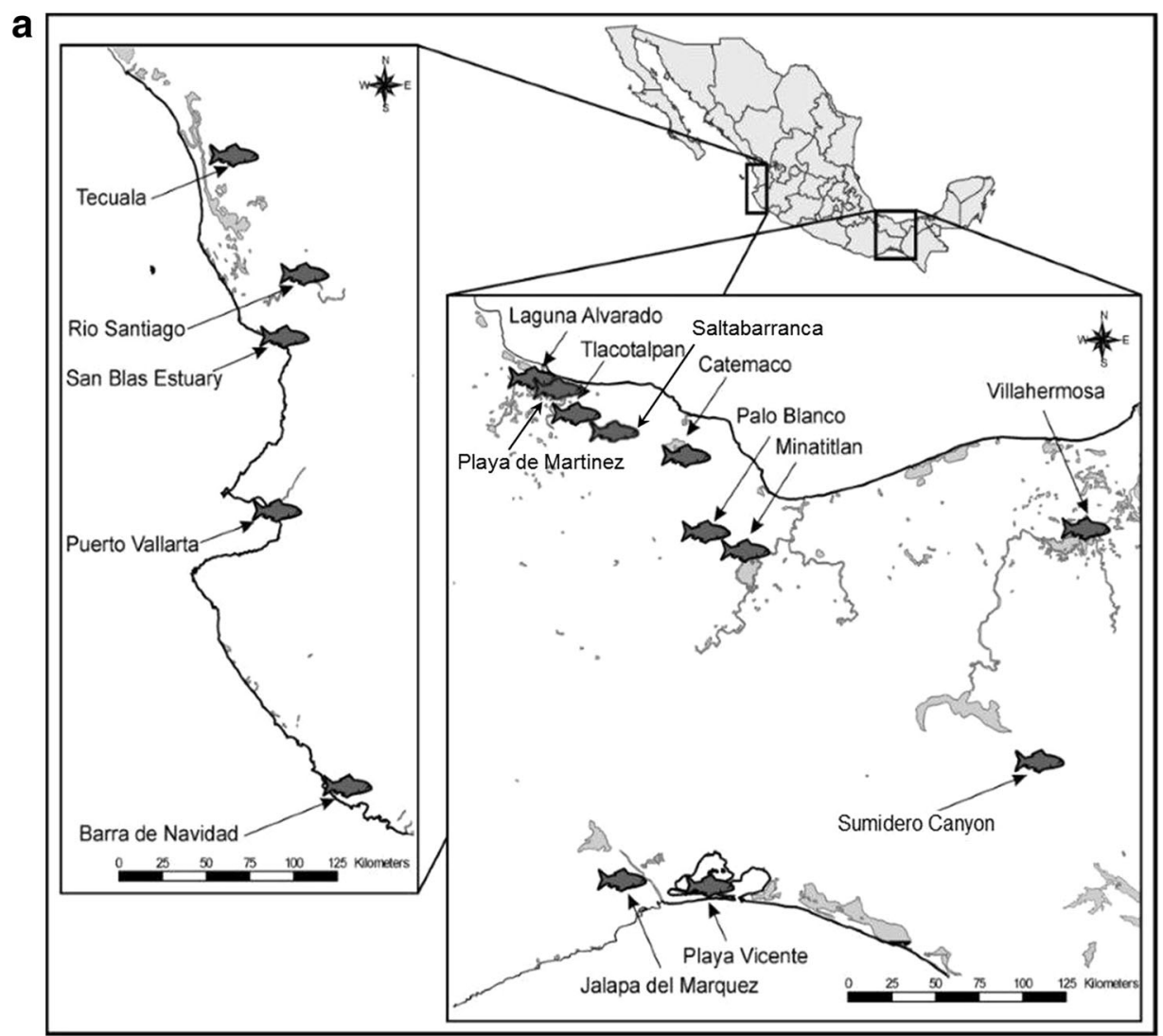

b

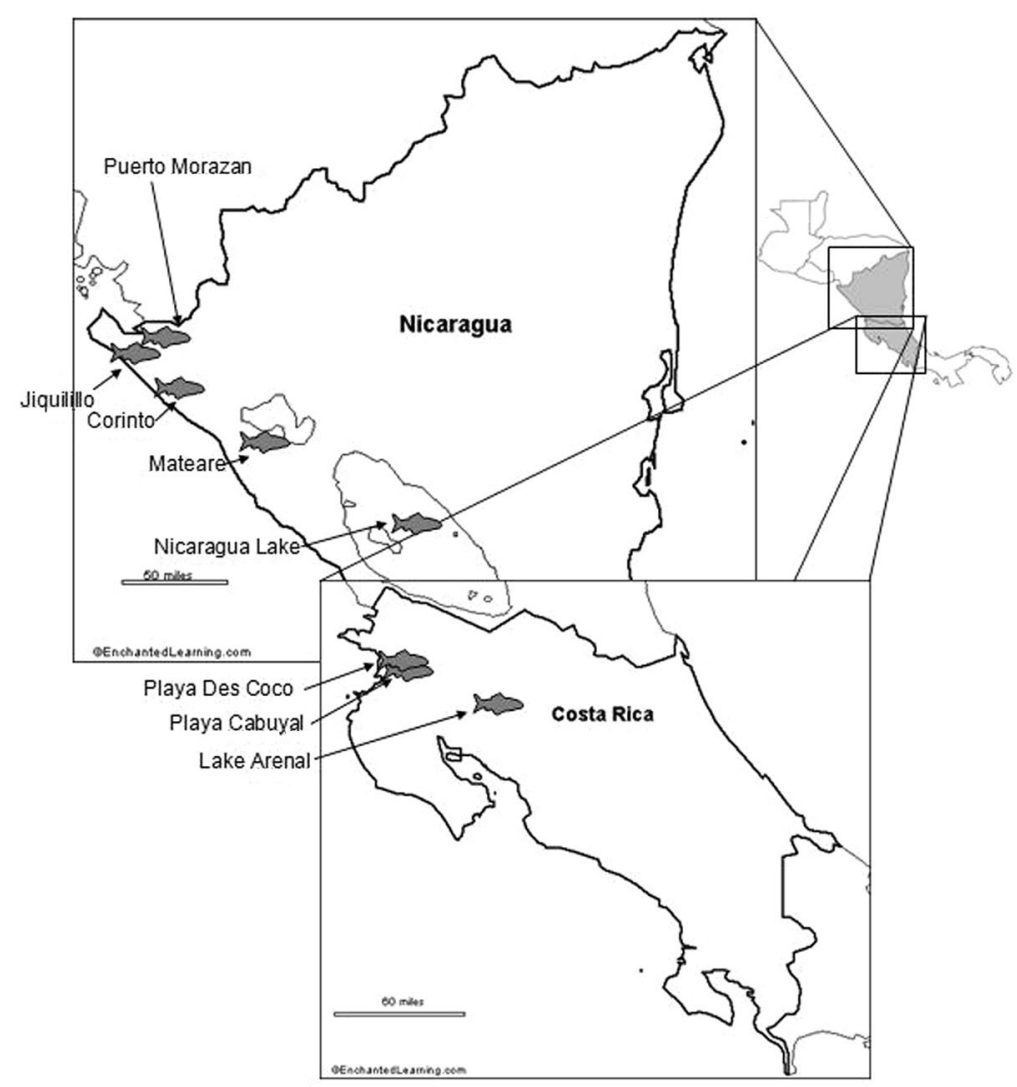


(Neuberger et al. 2000). For samples collected before 2001, approximately $0.5 \mathrm{~g}$ of homogenate was placed in a preweighed acid-washed test tube and then freeze-dried until reaching a constant mass. In order to express concentrations in terms of dry or wet weight, dry weights of samples were recorded and moisture content calculated. These dry samples were then placed in plastic, acid-washed tubes, and $0.25 \mathrm{~mL}$ of deionized water and $0.5 \mathrm{~mL}$ of $\mathrm{HNO}_{3}$ $(70 \%)$ was added. Samples were left overnight and then on the following day, loosely capped and placed in dry heating blocks at $100{ }^{\circ} \mathrm{C}$ for $4 \mathrm{~h}$. Following this, samples were diluted to $2.0 \mathrm{~mL}$ in deionized water and analyzed by continuous-flow cold vapour atomic absorption spectrophotometry (CVT-AAS, Perkin-Elmer 3030B with VGA-76; see Scheuhammer and Bond 1991).

For fish samples collected from 2001 onward, total $\mathrm{Hg}$ concentrations were determined directly using an automated mercury analyzer (AWA-254, Canalytical, Burlington, Ontario, Canada). Using a combustion/catalyst tube to macerate the sample, this process removes interfering elements in an oxygen-rich environment. A gold amalgamator then traps any $\mathrm{Hg}$ that occurs in the expelled gases; $\mathrm{Hg}$ content is determined by a dual-path length cuvette/spectrophotometer. For the average 0.020-g dry mass sample, the effective detection limit was $0.12 \mathrm{ng} \mathrm{Hg}$ or $0.006 \mu \mathrm{g} \mathrm{g}^{-1}$. Two methods were deployed to achieve quality control: (1) repeated concurrent analyses of procedural blanks, and (2) certified/in-house standard reference materials. The latter included: National Research Council of Canada (NRCC) dogfish liver (DOLT2), dogfish muscle (DORW-2), mussel tissue $\left(\mathrm{ERW}^{\circledR}-\mathrm{CE} 278\right)$, and tuna fish $\left(\mathrm{BCR}^{\circledR}-463\right)$. To assess analytical variability, duplicate sampling was performed. Furthermore, method accuracy was assessed through analysis of the concentration of certified reference materials (DOLT-3, TORT-2 from NRRC, and Oyster Tissue 1566b from NIST). To verify the comparability of results following method changes (e.g., before and after 2001), in-house standard reference materials from NWRC (pooled Herring Gull Larus argentatus egg samples) that have been repeatedly analyzed for $\mathrm{Hg}$ over multiple years were used. All results are reported as $\mu \mathrm{g} \mathrm{g}^{-1}$ dry weight, except for the wet weight conversions to determine toxicity thresholds. For the latter, we used weight toxicity thresholds for Osprey from Heinz et al. (2009).

\section{Stable Isotope Analysis}

Stable isotope analysis was performed using the same freeze-dried muscle homogenates used for mercury analyses. Detailed methods are described elsewhere (Elliott et al. 2014). Briefly, 1-mg subsamples were freeze-dried, loaded into tin cups and analyzed using a PDZ Europa ANCA-
GSL elemental analyzer interfaced to a PDZ Europa 20-20 isotope ratio mass spectrometer (IRMS; Sercon Ltd., Cheshire, UK) at the Stable Isotope Facility, University of California, Davis (http://www.stableisotopefacility.ucda vis.edu). Samples were analyzed for ${ }^{13} \mathrm{C} /{ }^{12} \mathrm{C}$ and ${ }^{15} \mathrm{~N} /{ }^{14} \mathrm{~N}$ isotopes. During analysis, samples were interspersed with several replicates of at least two different laboratory standards. The final delta values were presented in parts per thousand (\%) relative to international standards Vienna PeeDee Belemnite and Vienna Cañon Diablo Troilite $\left(\delta^{13} \mathrm{C}\right)$ and air $\left(\delta^{15} \mathrm{~N}\right)$, respectively. We accounted for variation in lipid content algebraically following Logan et al. (2008):

$\delta^{13} \mathrm{C}^{\prime}=\delta^{13} \mathrm{C}+\frac{7.415 \mathrm{C}: \mathrm{N}-22.73}{\mathrm{C}: \mathrm{N}+0.746}$

\section{Statistical Analysis}

Concentrations of contaminants in whole body fish composites were calculated as ([muscle mass $\mathrm{x}$ muscle concentration] + [composite carcass mass $\mathrm{x}$ composite carcass concentration] $) /($ sum of fish masses). For samples collected in 2002 ( $n=8$ pools), individual muscle fillets were not analyzed with the remaining carcasses. Therefore, we used linear regression equations for mercury and methyl-mercury to predict the whole body composite concentrations given only data from the carcasses (Elliott et al. 2007).

We conducted four types of data summary and analysis. First, we averaged total $\mathrm{Hg}$ for each fish species to determine whether there were interspecific differences in levels; we also correlated length of individual fish with $\mathrm{Hg}$ levels, because generally $\mathrm{Hg}$ levels are positively correlated with size in fish (Bank et al. 2007). Second, we graphed these average $\mathrm{Hg}$ values and compared them with conservative critical thresholds in forage fish associated with behavioral effects $\left(0.1 \mu \mathrm{g} \mathrm{g}^{-1}\right.$ wet weight $)$ and reproductive effects $\left(0.18 \mu \mathrm{g} \mathrm{g}^{-1}\right.$ wet weight) in Common Loons (Gavia immer) (Depew et al. 2012) to see which species or sample locations exceeded the thresholds recommended. See below for more discussion of threshold values. For these analyses, we converted dry weights to wet weight using the formula Wet Wt $=$ Dry Wt x $[1-(\%$ moisture/100 $)]$. Third, to see if we could detect any geographical patterns in $\mathrm{Hg}$ levels in fish, we averaged the $\mathrm{Hg}$ levels for each species by sample location and then conducted a nonmetric multidimensional scaling (nMDS) ordination (Bray-Curtis; Clarke and Gorley 2006). We took averages for $\mathrm{Hg}$ for each species, because there were multiple specimens from each location and statistically these were not independent (the data matrix was too sparse to calculate similarity matrices based on individual fish). Following nMDS ordination, we tested pairwise differences between fish samples 
in different regions using Analysis of Similarity (ANOSIM). We also conducted a cluster analysis (group linkage) to see whether sites were grouped by geographic location based on their fish species composition and $\mathrm{Hg}$ levels in fish.

We used linear mixed models in SAS (Proc. GLIMMIX in SAS Inst. 2000) to model the relationship between total $\mathrm{Hg}$ as response variable and various predicators. We used an Information-theoretic (IT) approach (Akaike's Information Criterion, $\mathrm{AIC}_{\mathrm{c}}$ corrected for small sample size; Burnham and Anderson 2002), developing a series of candidate models with different combinations of species, site location, $\delta^{13} \mathrm{C}$, and $\delta^{15} \mathrm{~N}$ (Table $\mathrm{S} 1$ ). We included site location and species in models, because $\mathrm{Hg}$ and stable isotope values vary according to those parameters.

\section{Results and Discussion}

Mean total $\mathrm{Hg}$ levels in whole body composite samples ranged from a high level of $0.18 \mu \mathrm{g} \mathrm{g}^{-1}$ (wet weight) in Scomberomorus sierra, a marine fish from Puerta Vallarta, Jalisco State, Mexico to a low of $0.005 \mu \mathrm{g} \mathrm{g}^{-1}$ in Tilapia Oreochromis niloticus from freshwater sites in Veracruz State, Mexico (Table 1). Even the greater concentrations reported are not particularly elevated compared with mean $\mathrm{Hg}$ in fish collected at many northern locations. For example, in a study of lakes across northeastern North America, $\mathrm{Hg}$ concentrations in whole carcass samples of brook trout (Salvelinus fontinalis) were $0.294 \mu \mathrm{g} \mathrm{g}^{-1}$ and in yellow perch (Perca flavescens) were $0.290 \mu \mathrm{g} \mathrm{g}^{-1}$ (Kamman et al. 2005). Mercury in fish samples from some individual lakes in the northeast of North America were more than an order of magnitude greater than those overall means. Similar or higher mercury levels in fish have been measured from hotspot sites across North America, such as former mercury or gold mines and other industrial activities, or lakes receiving particularly high deposition rates (Weech et al. 2004; Davis et al. 2008; Wyn et al. 2010). In contrast, the limited reports on mercury in fish from Mexico are consistent with our findings reported, with relatively low, $<0.1 \mu \mathrm{g} \mathrm{g}^{-1}$ w. w. concentrations reported in forage fish from sites in Mexico (Ruelas-Inzunza and Páez-Osuna 2005). Other data on mercury in fish from the region has been from mainly coastal and estuarine sites (ibid; García-Hernández et al. 2007). Mercury contamination may be greater around areas of Mexico where gold and silver mining was greatest, given the large quantities of mercury used in such mining in Mexico and elsewhere in Latin America (Nriagu 1994; Malm 1998; Mol et al. 2001). However, those mining regions in Mexico tend to be more arid, and so the biogeochemistry may not only be different, but also there are fewer water bodies that would

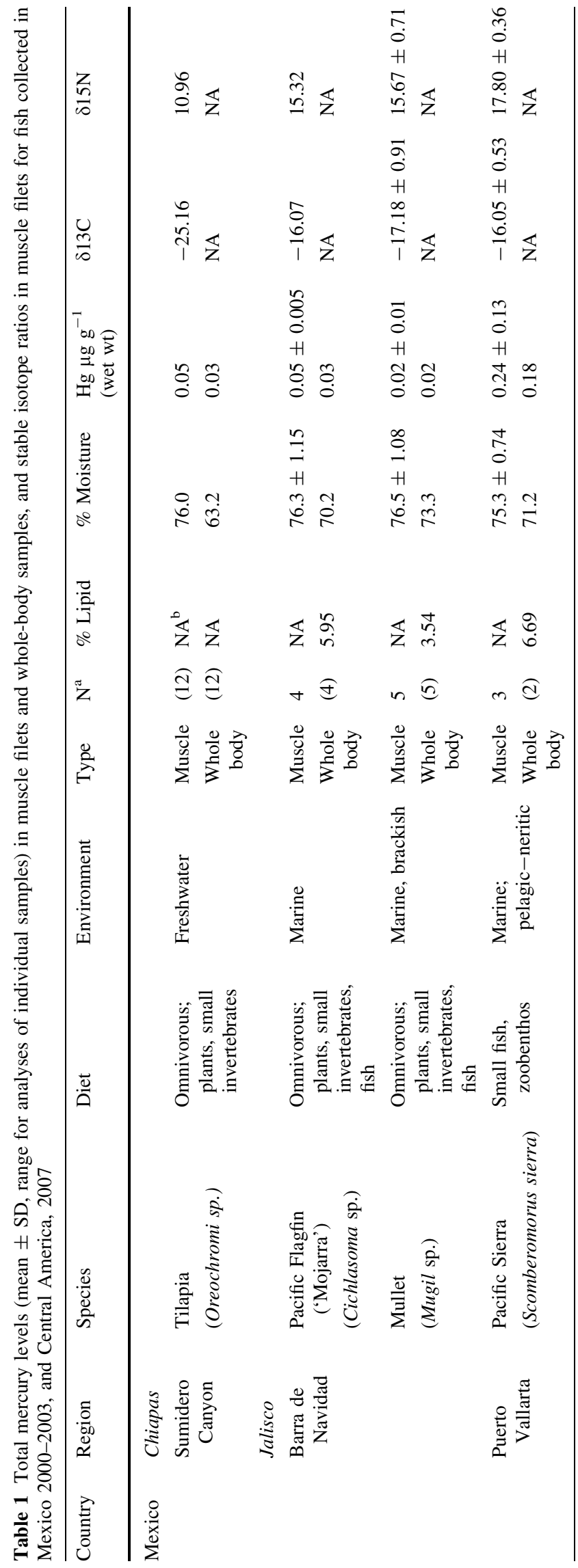




\begin{tabular}{|c|c|c|c|c|c|c|c|c|c|c|}
\hline$\frac{z}{\frac{Z}{n}}$ & 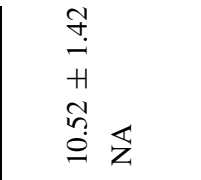 & $\begin{array}{l}I \\
0 \\
+1 \\
\infty \\
\dot{n}\end{array}$ & 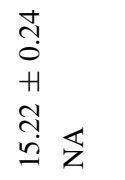 & 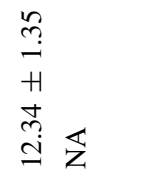 & 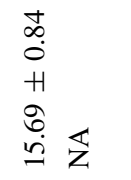 & $\begin{array}{l}\stackrel{0}{0} \\
\stackrel{0}{0} \\
\stackrel{+}{ \pm}\end{array}$ & 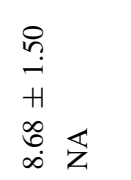 & 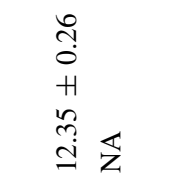 & 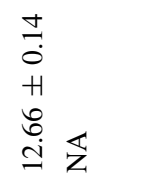 & 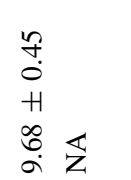 \\
\hline$\frac{0}{\infty}$ & $\begin{array}{l}n \\
a \\
+1 \\
+1 \\
n \\
\stackrel{a}{a} \\
\stackrel{1}{1}\end{array}$ & 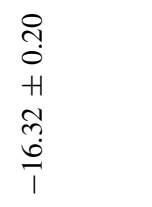 & 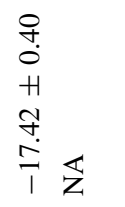 & 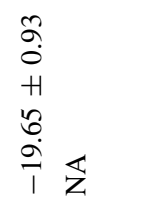 & 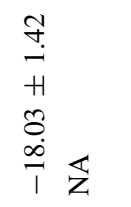 & 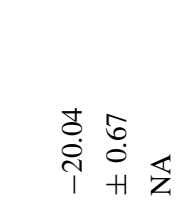 & 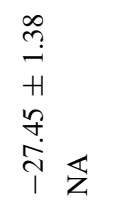 & $\begin{array}{l}\infty \\
n \\
0 \\
H \\
0 \\
0 \\
\stackrel{N}{1} \\
i\end{array}$ & $\begin{array}{l}8 \\
\dot{8} \\
+1 \\
0 \\
\stackrel{\oplus}{i} \mathbb{Z}\end{array}$ & $\begin{array}{l}\text { ते } \\
0 \\
H \\
\infty \\
0 \\
\stackrel{0}{0} \\
1 \\
1\end{array}$ \\
\hline 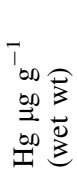 & 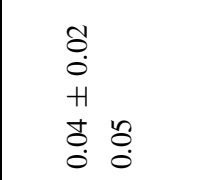 & $\begin{array}{l}8 \\
0 \\
0 \\
H \\
+1 \\
\stackrel{1}{0} \\
\stackrel{0}{0}\end{array}$ & 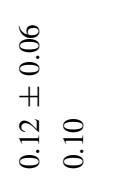 & 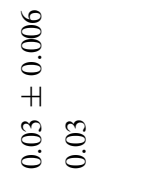 & $\begin{array}{l} \pm \\
\stackrel{0}{0} \\
H \\
0 \\
0 \\
0 \\
0\end{array}$ & \begin{tabular}{ll}
0 & \multicolumn{1}{c}{} \\
0 & 0 \\
0 & 0 \\
$H$ & +1 \\
0 & 0 \\
0 & 0 \\
0 & 0
\end{tabular} & 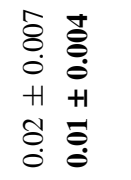 & $\begin{array}{ll} \pm & g \\
0 & 0 \\
0 & 0 \\
H & H \\
n & \pm \\
0 & 0\end{array}$ & 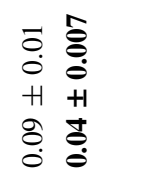 & $\begin{array}{ll}0 & 0 \\
0 & 0 \\
0 & 0 \\
H & +1 \\
0 & +1 \\
0 & 0 \\
0 & 0\end{array}$ \\
\hline $\begin{array}{l}0 \\
\vdots \\
.00 \\
0 \\
\sum_{0}^{0} \\
0\end{array}$ & 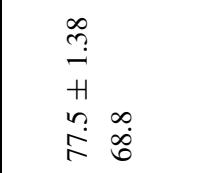 & $\begin{array}{l}\stackrel{a}{\vec{i}} \\
+ \\
\stackrel{H}{i} \infty \\
\stackrel{8}{0}\end{array}$ & $\begin{array}{l}\infty \\
n \\
0 \\
+1 \\
+ \\
\dot{n} \\
\stackrel{8}{8}\end{array}$ & $\begin{array}{l}\vec{m} \\
\dot{r} \\
H \\
\dot{\nabla} \\
\stackrel{\nabla}{i}\end{array}$ & 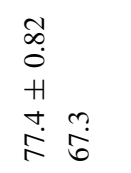 & 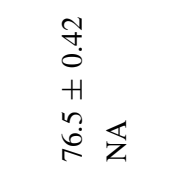 & $\begin{array}{l}\stackrel{3}{6} \\
\stackrel{+}{H} \\
\stackrel{\infty}{\circ} \\
\stackrel{0}{\circ} \varangle\end{array}$ & 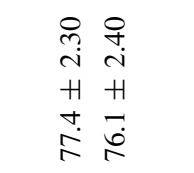 & $\begin{array}{l}\vec{\sigma} \\
\dot{H} \\
\dot{H} \\
\stackrel{m}{+} \\
\stackrel{+}{Z}\end{array}$ & \begin{tabular}{l}
$\stackrel{2}{5}$ \\
0 \\
+1 \\
+ \\
$\infty$ \\
$\infty$ \\
\hdashline
\end{tabular} \\
\hline $\begin{array}{l}\text { : } \\
\text { : } \\
\text { s0 }\end{array}$ & $\overleftrightarrow{z} \stackrel{\infty}{i}$ & $\overleftrightarrow{z} \stackrel{a}{a}$ & $\stackrel{\infty}{=}$ & $\overleftrightarrow{z} \stackrel{m}{m}$ & 危 $\underset{+}{\stackrel{f}{+}}$ & 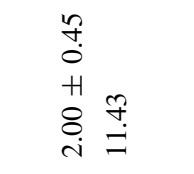 & 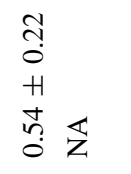 & $\begin{array}{l}\stackrel{a}{0} \\
+1 \\
\text { ते } \\
\stackrel{0}{0}\end{array}$ & $\overleftrightarrow{z} \overleftrightarrow{z}$ & $\overleftrightarrow{z} \stackrel{n}{r}$ \\
\hline$\ddot{Z}$ & $n \mathcal{I}$ & in $\sqrt{6}$ & $m \widehat{0}$ & $n \sqrt{n}$ & $n \sqrt{n}$ & $n \sqrt{6}$ & $+\bigoplus$ & $m \approx$ & $\sim \widehat{d}$ & $n \sqrt{6}$ \\
\hline 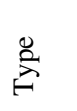 & 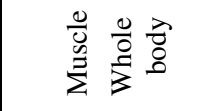 & 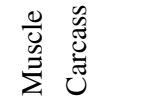 & 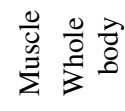 & 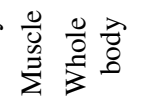 & 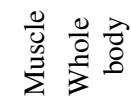 & 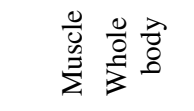 & 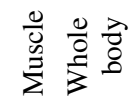 & 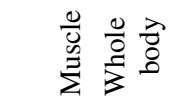 & 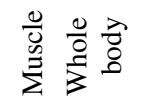 & 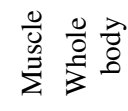 \\
\hline 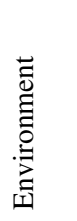 & 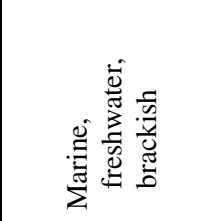 & 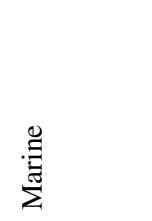 & $\begin{array}{l}\mathscr{E} \\
\stackrel{\Xi}{\Sigma}\end{array}$ & 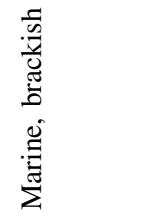 & 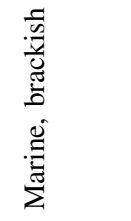 & 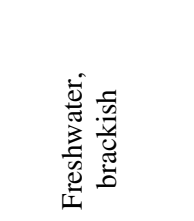 & 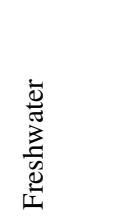 & 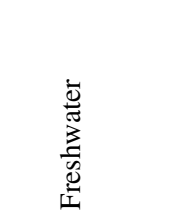 & 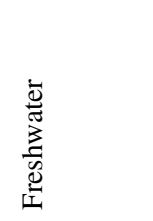 & 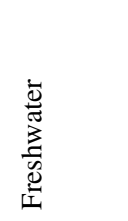 \\
\hline 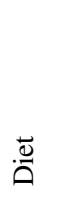 & 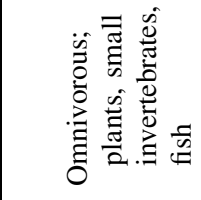 & 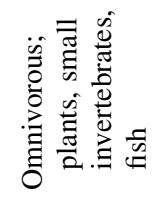 & 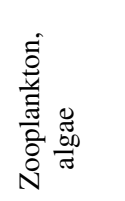 & 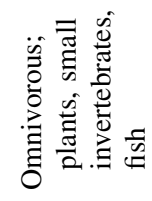 & 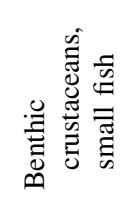 & 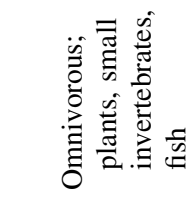 & 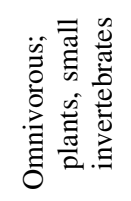 & 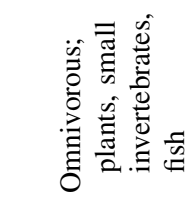 & 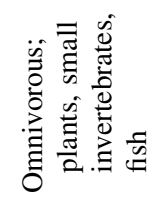 & 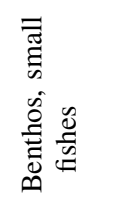 \\
\hline 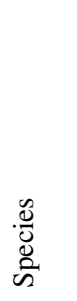 & 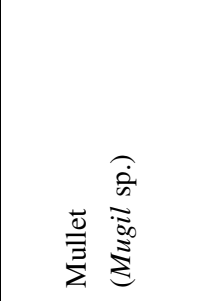 & 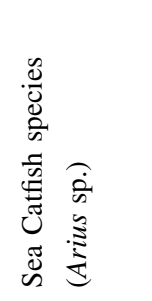 & 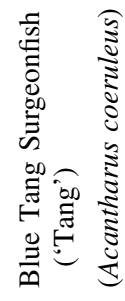 & 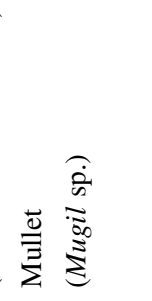 & 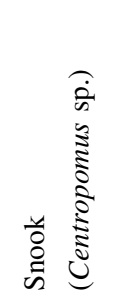 & 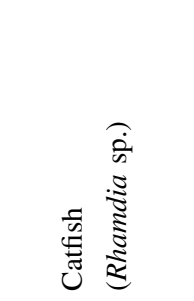 & 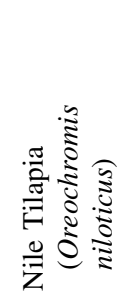 & 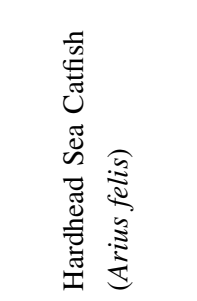 & 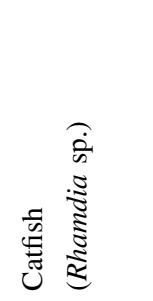 & 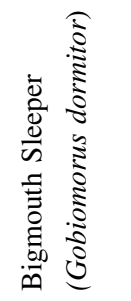 \\
\hline $\begin{array}{l}\tilde{\Xi} \\
.00 \\
\stackrel{0}{\simeq}\end{array}$ & 焉 & 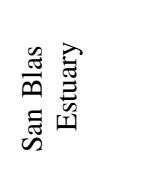 & & 胥 & & 胥 & 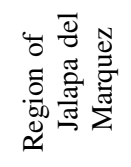 & 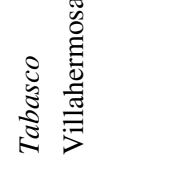 & & \\
\hline
\end{tabular}




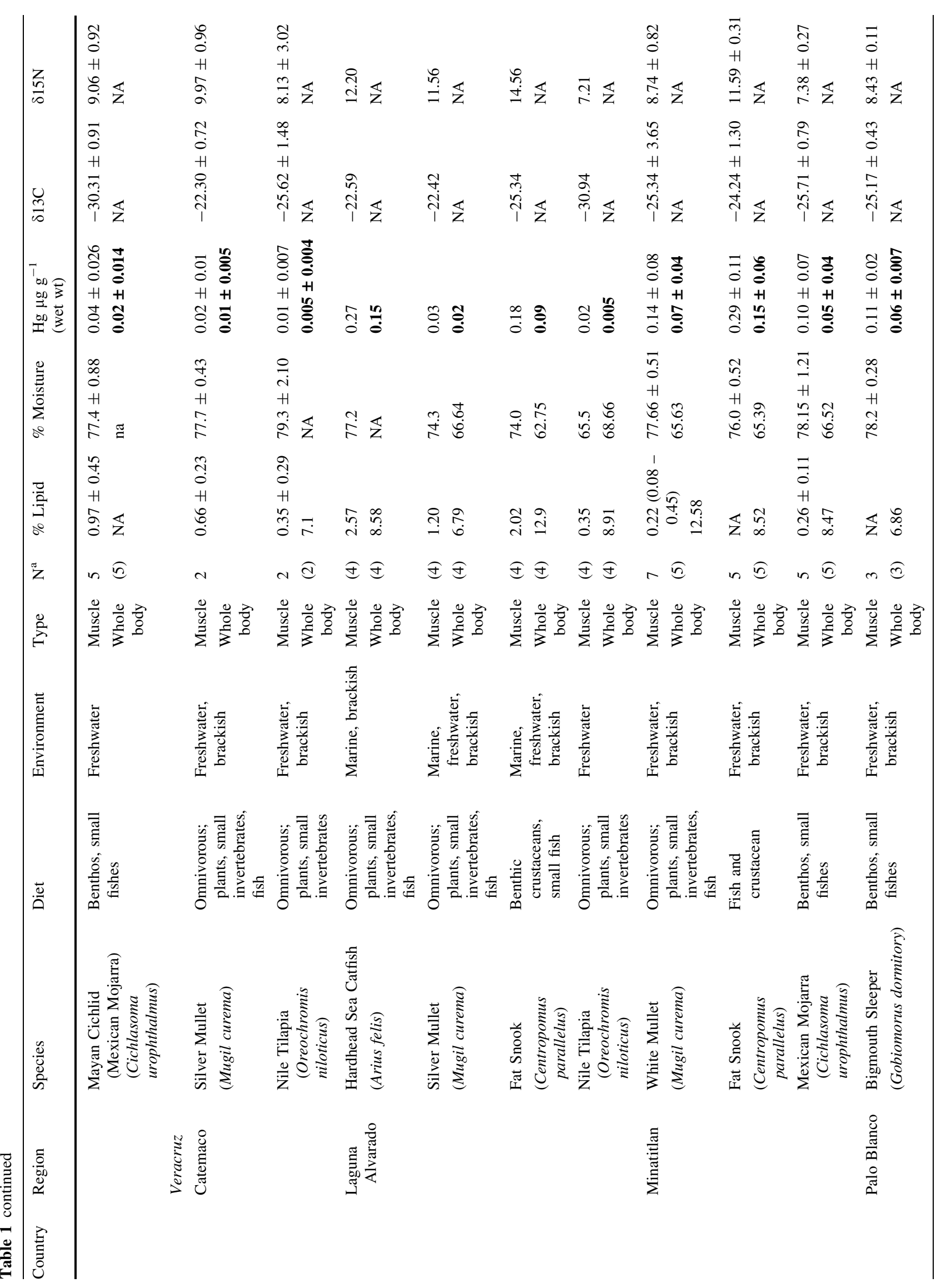




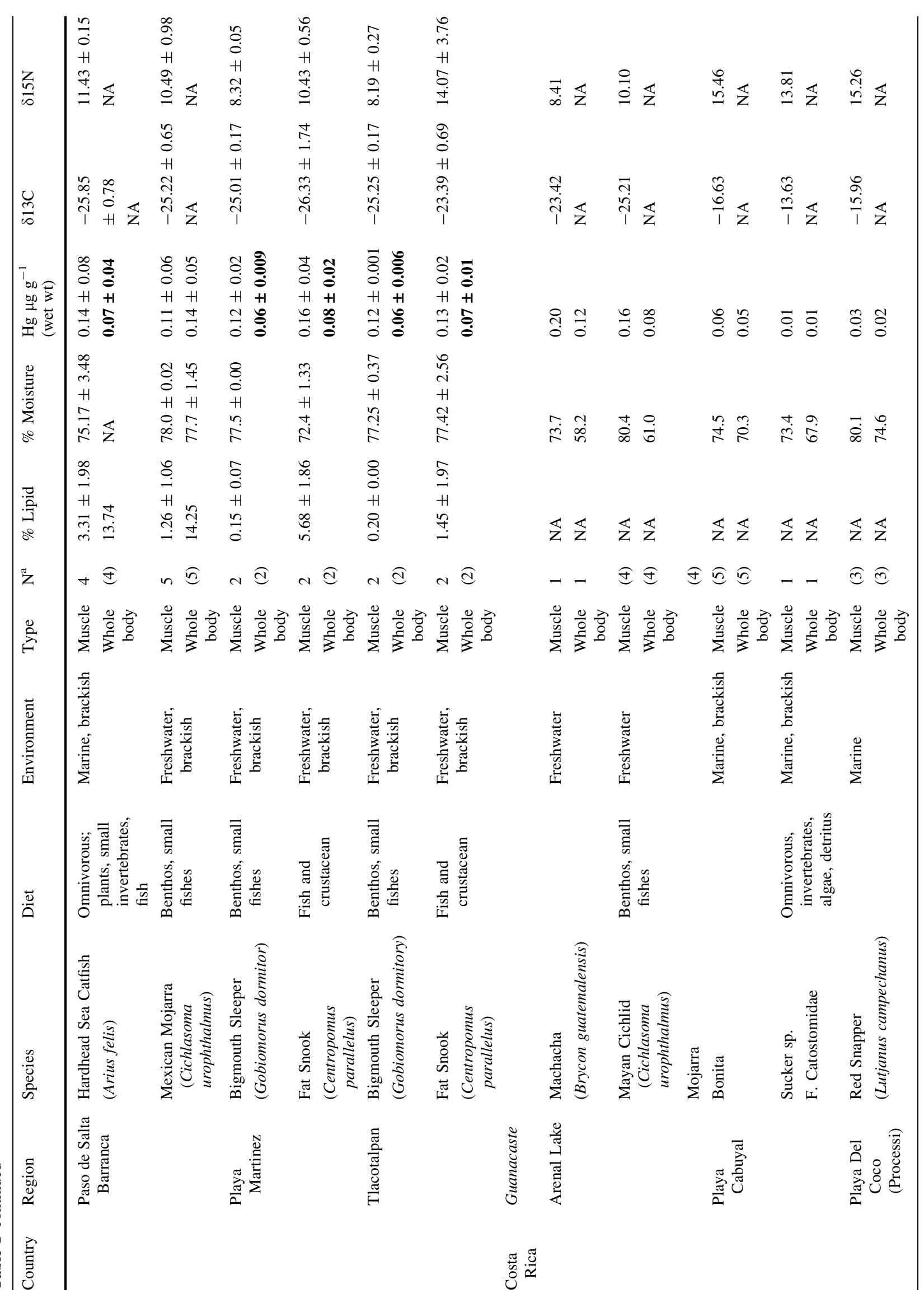




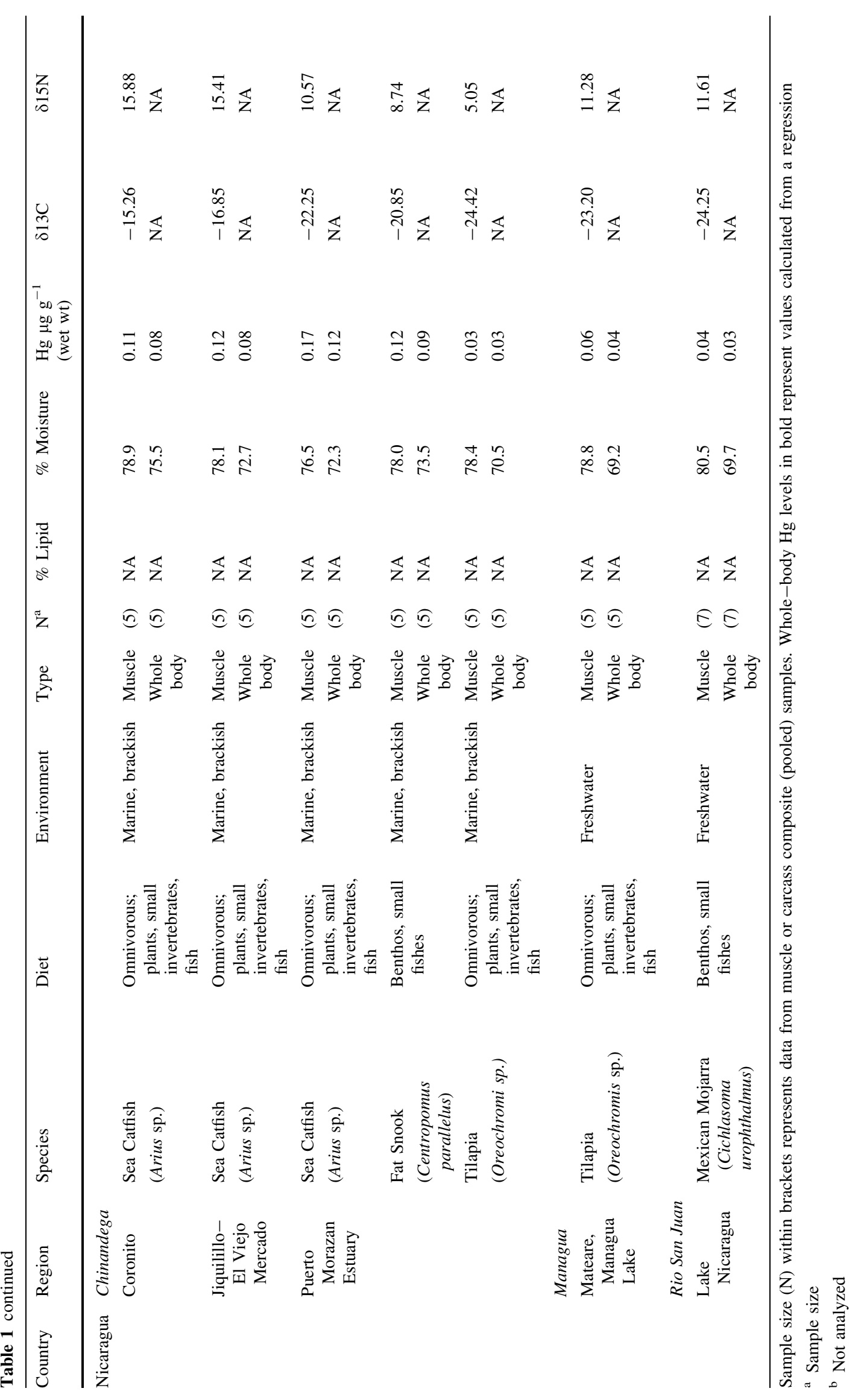


attract wintering osprey and other water birds compared to the coastal wetlands. Thus, fish-eating birds may be present in smaller numbers.

Mean Hg levels (converted to wet weight) exceeded the published conservative toxicity threshold range in forage fish $\left(0.10-0.18 \mu \mathrm{g} \mathrm{g}^{-1}\right)$ for four $(28.6 \%)$ taxa (Scomberomorus sierra, Centropomus spp., Brycon guatemalensis, Centropomus paralellus), whereas the threshold was within one standard deviation for some of these taxa, as well as Ariopsis felis (Fig. 2). Geographically, none of the fish from Central American sites had $\mathrm{Hg}$ levels that exceeded the toxicity threshold, whereas average $\mathrm{Hg}$ levels were above the toxicity threshold at two sites in Mexico (Puerto Vallarta and San Blas Estuary) or were within one standard deviation for five $(21 \%)$ sites (Arenal Lake, Laguna Alvarado, Minatitlan, Puerto Morazan Estuary, and Tecuala Market; Fig. 3). The mercury threshold value of $0.1 \mu \mathrm{g} \mathrm{g}^{-1}$ w.w. in forage fish is a screening value for risk assessment and is based on field studies of common loons. It is the midpoint (0.05-0.15 $\mu \mathrm{g} \mathrm{g}^{-1}$ w.w.) of fish $\mathrm{Hg}$ values associated with altered behaviours. Although behavioural changes have been found to be sensitive endpoints for other contaminants (Harris and Elliott 2011), they also are difficult to evaluate and control for rigorously, particularly in the field. The reproductive impairment threshold of $0.18 \mu \mathrm{g} \mathrm{g}^{-1} \mathrm{w}$.w. also is a screening value and is lower than the $0.25 \mu \mathrm{g} \mathrm{g}^{-1}$ w.w. conservative screening value in an avian diet proposed by Shore et al. (2011). There is little in the way of comparative toxicity data for mercury in fish eating birds. Our original study species, the osprey, was found to be among the more mercury sensitive species based on egg injection experiments (Heinz et al. 2009). However, nest success of osprey populations was within the normal range at a number of sites with greater mercury concentrations in forage fish than the mean values that we report in the present study (Desgranges et al. 1998; Anderson et al. 2008).

Nitrogen stable isotopes $\left(\delta^{15} \mathrm{~N}\right)$ were positively correlated with carbon stable isotopes $\left(\delta^{13} \mathrm{C}\right.$, lipid-corrected $)$ across habitats $\left(t_{106}=9.83 ; \quad P<0.00001 ; \quad R^{2}=0.48\right.$, Fig. 4a), as marine habitats (enriched in ${ }^{13} \mathrm{C}$ ) usually have longer food chains and therefore are more enriched in $\delta^{15} \mathrm{~N}$. They were similarly correlated within the estuarine habitat $\left(t_{22}=3.48, P=0.002 ; R^{2}=0.33\right)$, but not in either the freshwater or marine habitat (all $P>0.05$ ). Carbon stable isotope ratios were good signatures for habitat, with $\delta^{13} \mathrm{C}$ usually $<-22$ in freshwater and $>-17$ in marine habitats, with estuarine fish largely in between.

$\mathrm{Hg}$ was not correlated with $\delta^{13} \mathrm{C}$ across all habitats combined or within any of the three habitats (all $P>0.05$ ). $\mathrm{Hg}$ was correlated with $\delta^{15} \mathrm{~N}$ in freshwater $\left(t_{68}=3.21\right.$, $P=0.002$, Fig. 4b) and marine $\left(t_{13}=3.10, P=0.009\right.$, Fig. 4b), but not estuarine $(P>0.05)$ habitats. Thus, fish
Fig. 2 Average (SD as error bar where available) $\mathrm{Hg}$ levels ( $\mu \mathrm{g} \mathrm{g}^{-1} /$ wet weight) grouped by overall species means for forage fish samples collected 2000-2003. Samples are a mix of composites and calculated composite values from a mix of single composite values and means from individual muscle values. Dotted horizontal lines show putative toxicity thresholds for avian consumers: the first $\left(0.1 \mu \mathrm{g} \mathrm{g}^{-1}\right)$ is the threshold for adverse behavioural impacts in adult Common Loons (Gavia immer). The $0.18 \mu \mathrm{g} \mathrm{g}^{-1}$ correspond to $\mathrm{MeHg}$ levels in prey fish associated with reproductive impairment in wild adult loons (Depew et al. 2012)

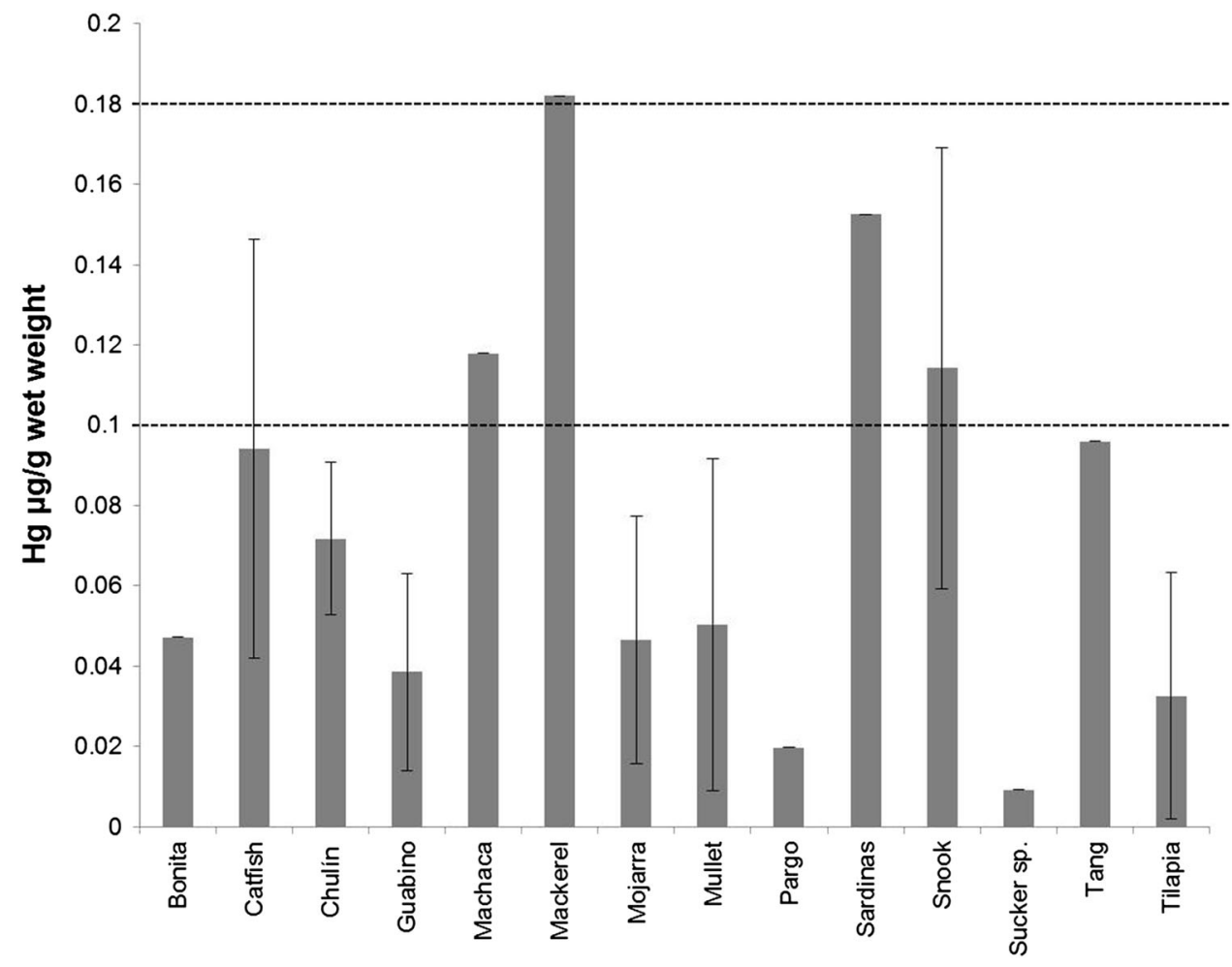




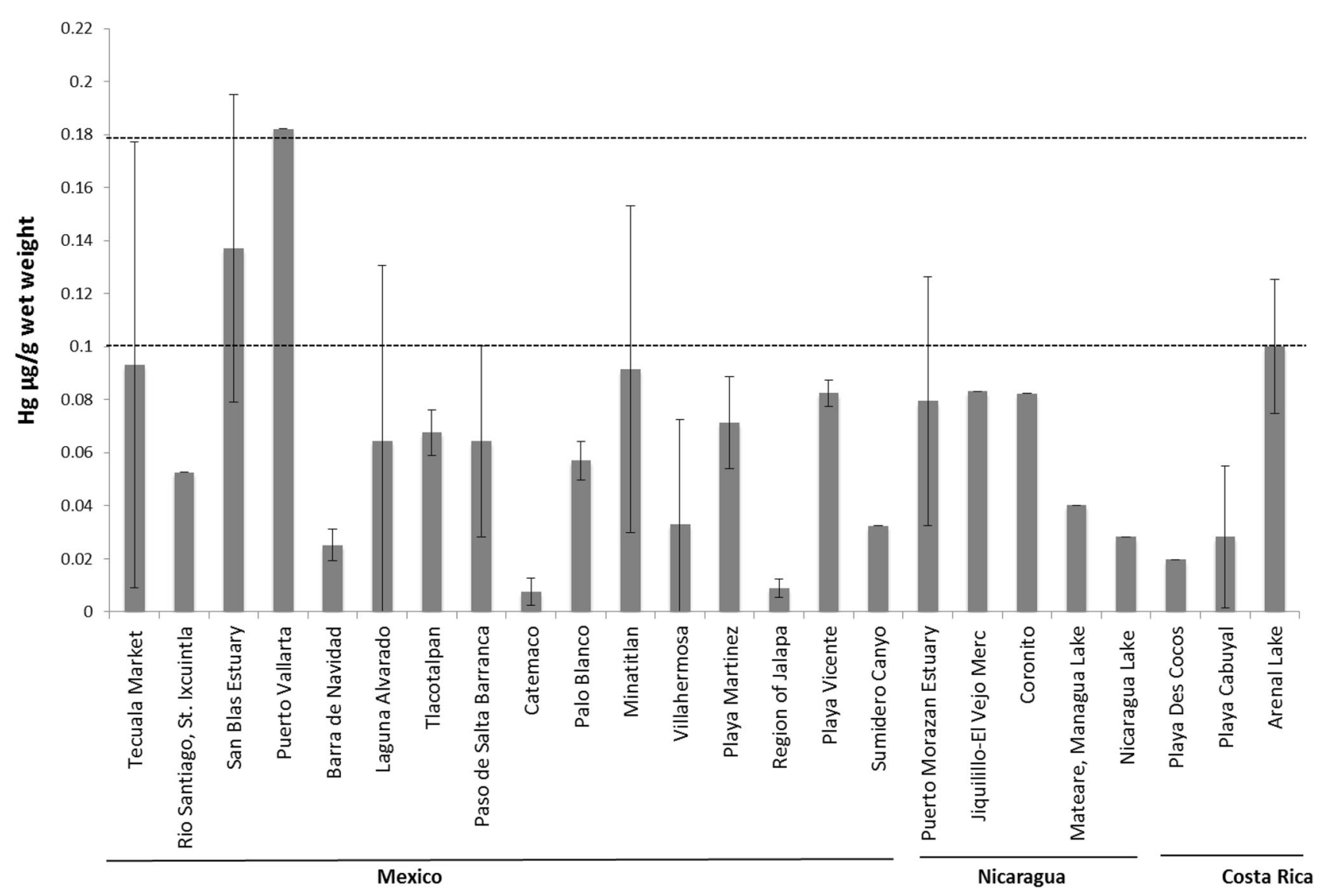

Fig. 3 Average (SD as error bar where available) $\mathrm{Hg}$ levels ( $\mu \mathrm{g} \mathrm{g}^{-1} /$ wet weight) for forage fish collected from Mexico (2000-2003) and Central American fish (2007), by location. Samples are a mix of composites and calculated composite values from a mix of single composite values and means from individual muscle values. Dotted

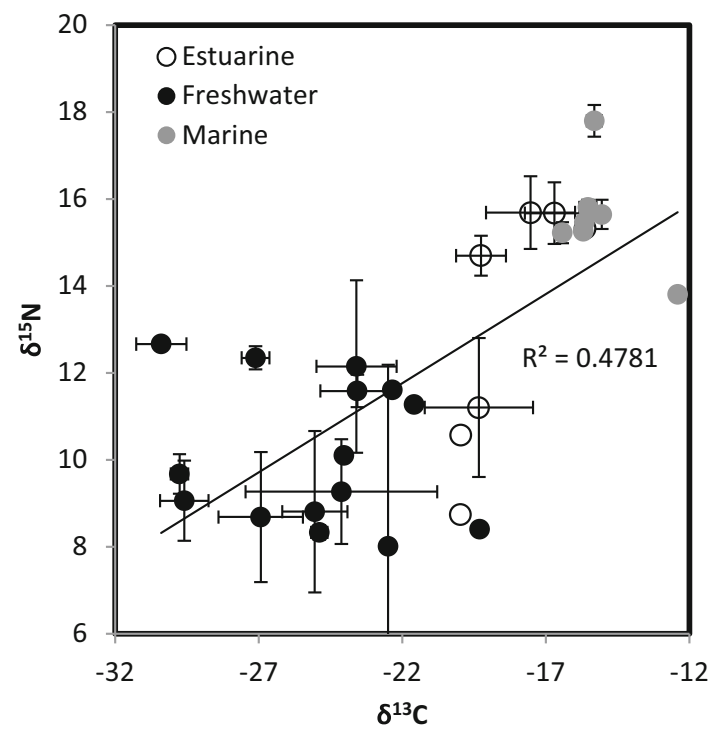

Fig. 4 a Values for $\delta^{15} \mathrm{~N}$ plotted against $\delta^{13} \mathrm{C}$ in forage fish from Mexico, 2000-2003 and Central America, 2007; b concentrations of mercury plotted against $\delta^{15} \mathrm{~N}$ in forage fish from Mexico, 2000-2003 lines show toxicity thresholds: the first $\left(0.1 \mu \mathrm{g} \mathrm{g}^{-1}\right)$ is the threshold for adverse behavioural impacts in adult Common Loons (Gavia immer). The $0.18 \mu \mathrm{g} \mathrm{g}^{-1}$ correspond to $\mathrm{MeHg}$ levels in prey fish associated with s reproductive impairment in wild adult loons (Depew et al. 2012)

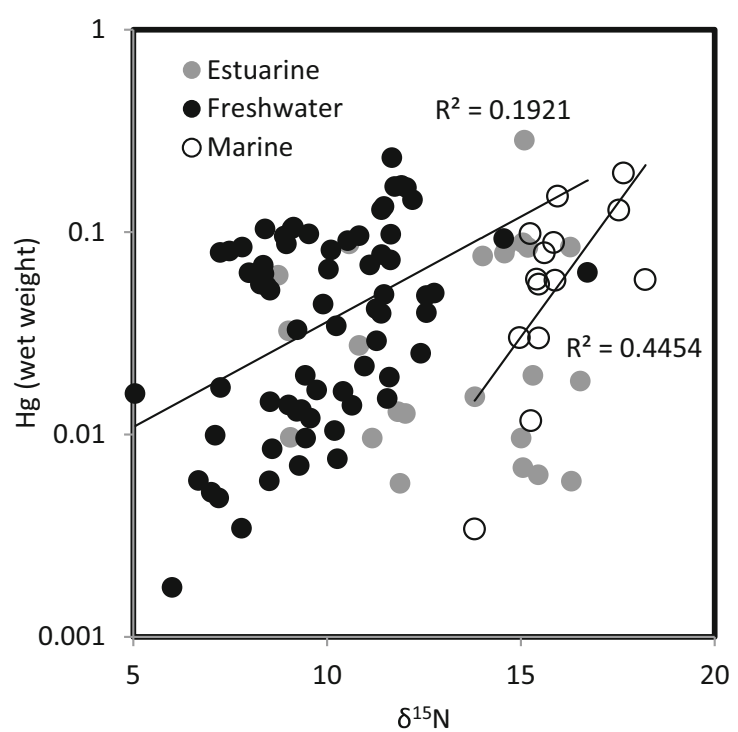

and Central America, 2007. Regression lines are fitted for freshwater and marine fish, and were not significant for estuarine species 
feeding at higher trophic levels had higher $\mathrm{Hg}$. In the estuarine environment, anthropogenic inputs, movement between fresh and saltwater, and habitat differences may have altered the $\delta^{15} \mathrm{~N}$ levels at the base of the food web, making $\delta^{15} \mathrm{~N}$ a poor indicator of trophic level. Indeed, similar processes among different lakes and river systems may explain why the $R^{2}$ value was also lower for freshwater than marine systems. In the marine environment, larger predatory fish, such as mackerel (Scomberomorus sierra) had both high $\delta^{15} \mathrm{~N}(\sim 18)$ and $\mathrm{Hg}\left(\sim 0.07 \mu \mathrm{g} \mathrm{g}^{-1}\right)$, whereas other fish, such as northern red snapper (Lutjanus sp.) had both lower $\delta^{15} \mathrm{~N}(\sim 15)$ and $\mathrm{Hg}\left(\sim 0.01 \mu \mathrm{g} \mathrm{g}^{-1}\right)$. When averaged across species in the marine environment, variation in $\delta^{15} \mathrm{~N}$ explained $60 \%$ of the variation in $\mathrm{Hg}$. In contrast, $\mathrm{Hg}$ levels were highly variable in brackish, estuarine water. Some apparently more marine, higher trophic level species, such as mullet, mojarra, and sardines, varied between 0.01 and $0.18 \mu \mathrm{g} \mathrm{g}^{-1} \mathrm{Hg}$, whereas more freshwater, lower trophic level species, such as catfish, snook, Mugil sp., and Rhamdia sp., likewise varied between 0.02 and $0.09 \mu \mathrm{g} \mathrm{g}^{-1}$. Within freshwater systems, the highest levels of $\mathrm{Hg}\left(0.08 \mu \mathrm{g} \mathrm{g}^{-1}\right)$ were from catfish (Arius fells) with relatively high trophic level $\left(\delta^{15} \mathrm{~N} \sim 12.4\right)$, whereas the lowest levels were in tilapia (Oreochromis niloticus) in Oaxaca and Chiapas, tilapia (Chichlasoma uropthalmus) in Tabasco, and guabino (Gobiomorus dormitor) in Tabasco with $\mathrm{Hg} \sim 0.01-0.02 \mathrm{ug} / \mathrm{g}$ and $\delta^{15} \mathrm{~N} \sim 8-9$. However, levels were quite variable. For instance, the guabino in Veracruz had $\mathrm{Hg} \sim 0.06$, although they had $\delta^{15} \mathrm{~N}$ of 8.3.

According to nMDS ordination there were some geographic patterns in fish species and $\mathrm{Hg}$ concentrations (Figs. 5, 6). However, the initial nMDS (Fig. 5) had three strong outliers-Playa Cabuyal (Costa Rica), Playa del Coco (Processi, Nicaragua) and Puerto Vallarta (Mexico). We removed these outliers in a second ordination (Fig. 6) to enable us to better determine patterns in species composition and $\mathrm{Hg}$ levels. On axis 1 of the ordination, sites from inland, the Gulf of Tehauntepec, the Bay of Campeche, and most sites from Nicaragua were on the right side of the ordination. Most sites from the Pacific were on the centre of the ordination, and the one site from Costa Rica on the left. Overall the ANOSIM demonstrated significant differences among areas based on fish species distributions and mercury levels (global $R=0.294$, $P=0.002$ ). Significant pairwise differences occurred between fish species composition and total $\mathrm{Hg}$ between the Pacific Coast of Mexico and Bay of Campeche $(R=0.36$, $P=0.024)$, and marginally significant differences between the Bay of Campeche and the Gulf of Tehuantepec ( $R=0.429, P=0.056$ ), between the Bay of Campeche and Nicaragua $(R=0.23, P=0.067)$, between the Pacific and Inland $(R=0.482, P=0.067)$ and between the Pacific and Nicaragua $(R=0.2, P=0.095)$. We identified seven groups at $35 \%$ similarity from the cluster analysis; there was considerable mixing of geographic locations (Figs. S1 and S2). The linear mixed model indicated that species and site location had important influences on total $\mathrm{Hg}$; however, the best model included site and $\delta^{15} \mathrm{~N}$ (Table 2).

There is potential variability around the precise locations of fish samples from small local markets. However, those retailers invariably stated that the small forage species were very local in origin. Thus, we can assume with some confidence that the geographical comparison we conducted does reflect real spatial differences. There was, however, some confounding of the ordination analyses by differences in fish species distributions. Substantial variation in $\mathrm{Hg}$ concentrations can occur in marine fish which can be influenced by factors such as point source pollution, various abiotic and biotic factors that influence $\mathrm{MeHg}$ production, as well as diet and local prey dynamics (Bank et al. 2007).
Fig. 5 Nonmetric multidimensional scaling ordination of mercury concentrations in forage fish for all 24 sites in Mexico, 2000-2003, and Central America, 2007

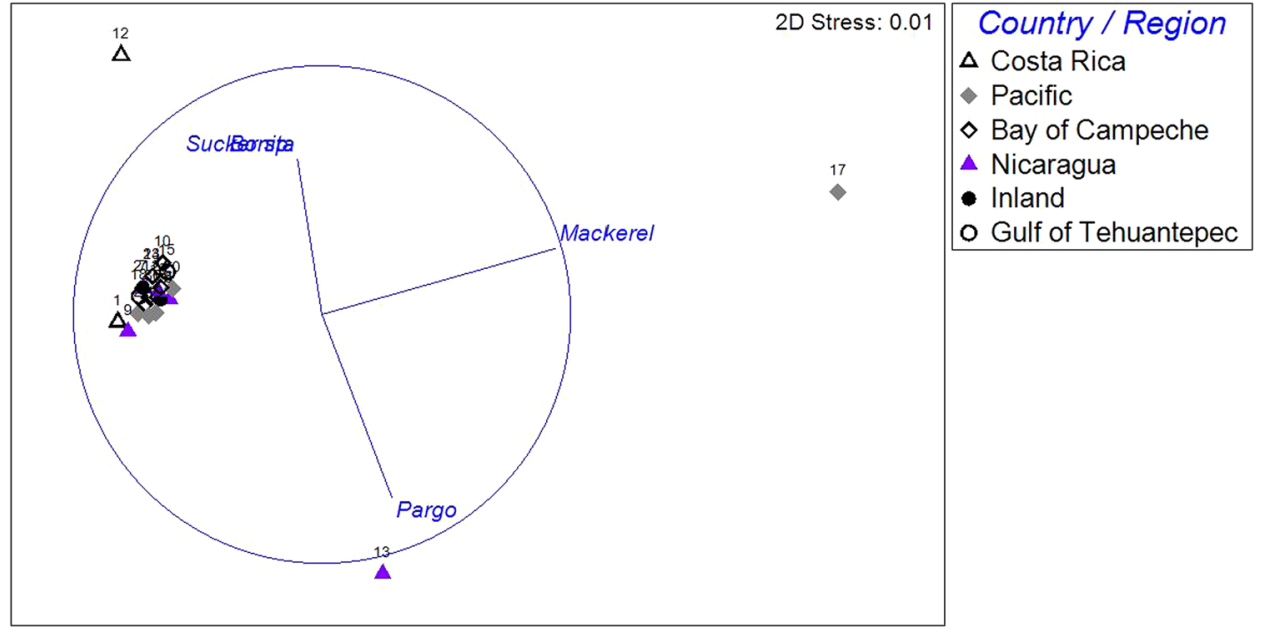




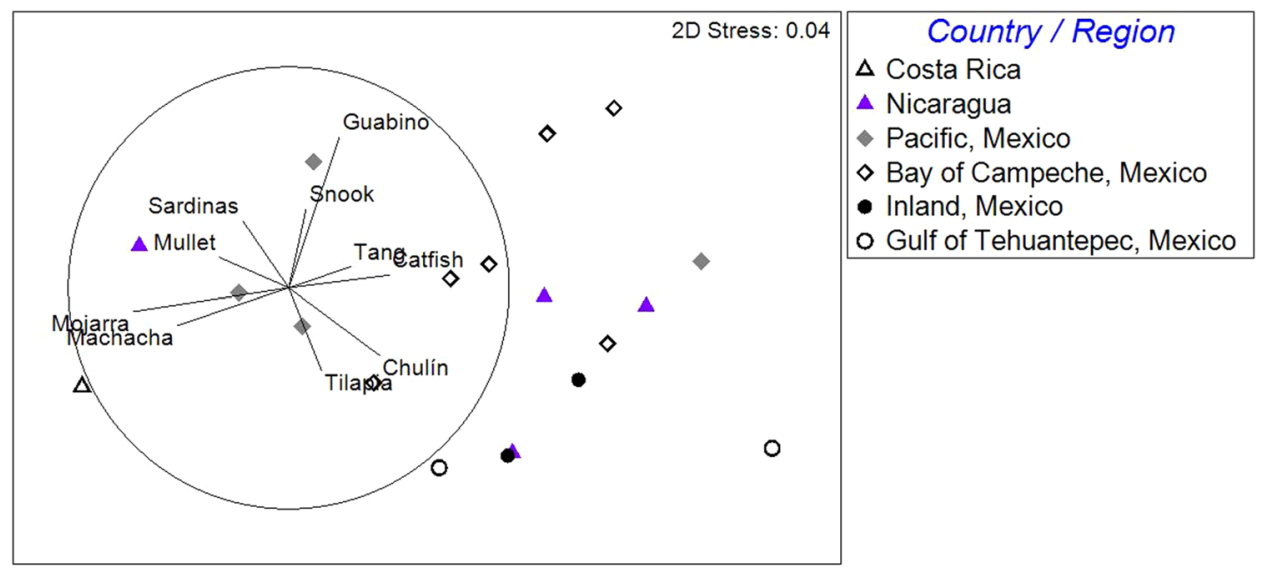

Fig. 6 Nonmetric multidimensional scaling ordination of mercury concentrations in forage fish from Mexico and Central America, with outliers removed. Site codes are (all sites in Mexico, unless stated otherwise): $1=$ Arenal Lake (Costa Rica), $2=$ Barra de Navidad, $3=$ Catemaco, $4=$ Coronito (Nicaragua), $5=$ Jiquilillo-El Vejo Merc (Nicaragua), $6=$ Laguna Alvarado, $7=$ Mateare, Managua Lake (Nicaragua), $8=$ Minatitlan, $9=$ Nicaragua Lake (Nicaragua), $10=$ Palo Blanco, $11=$ Paso de Salta Barranca, $12=$ Playa Cabuyal, 13 = Playa del Coco, 14 = Playa Martinez, $15=$ Playa

Table 2 Modelling results for linear mixed models with $\mathrm{Hg}$ as dependent variable and various candidate models for site, species, and stable isotopes $\left(\delta^{13} \mathrm{C}\right.$ and $\left.\delta^{15} \mathrm{~N}\right)$. Only models with $\Delta \mathrm{AIC} \leq 2.0$ are included

\begin{tabular}{lllll}
\hline Model parameters & $\Delta$ AIC & $\chi^{2}$ & df & $P$ \\
\hline Site & 0.00 & 38.18 & 9 & $<0.0001$ \\
$\delta^{15} \mathrm{~N}$ & & 22.47 & 1 & $<0.0001$ \\
\hline
\end{tabular}

The mercury concentrations in forage fish measured in this study do not account for the high mercury concentrations reported in many osprey populations on the breeding grounds (Hughes et al. 1997; Desgranges et al. 1998; Elliott et al. 2000; Hopkins et al. 2007; Anderson et al. 2008; Henny et al. 2009; Guigueno et al. 2012). Consistent with our previous study of persistent organic pollutants in western migratory populations of osprey, primary sources of contamination appear to be in the north. That is consistent with the much greater industrial development of the landscapes, particularly in the United States and the continuing legacy of contaminated sites, such as former mercury and gold mines in both the United States and Canada (Henny et al. 2002; Weech et al. 2004, 2006; Anderson et al. 2008). Our results do not preclude the possibility of other $\mathrm{Hg}$ contaminated hotspots in Mexico and Central America. The situation also may be different for ospreys breeding in eastern North America, many of which winter in South America, including the Amazon basin (Martell et al. 2014).
Vicente, $16=$ Puerto Morazan Estuary, Nicaragua, $17=$ Puerto Vallarta, $18=$ Region of Jalapa del Marquez, $19=$ Rio Santiago, St. Ixcuintla, $20=$ San Blas Estuary, $21=$ Sumidero Canyon, 22 = Tecuala Market, 23 = Tlacotalpan, $24=$ Villahermosa. Species acronyms are: Guabino $=$ Gobiomorus dormitor, Snook $=$ Centropomus parallelus, Tang = Acantharus coeruleus, Catfish $=$ Ariopsis felis, Chulin $=$ Rhamdia sp., Tilapia $=$ Oreochromis niloticus, Mojarra = Cichlasoma urophthalmus, Machacha = Brycon guatemalensis, Mullet = Mugil sp., Sardinas = Centropomus sp.

Sources of $\mathrm{Hg}$ contamination in Mexico and Central America have not been well researched, and this paper provides further baseline information for the region. Of interest, we found that $\mathrm{Hg}$ levels were above the conservative screening level toxicity thresholds for some fish species some sampling locations, but the values are not really cause for concern. The limited published data highlights the need for further surveys of diet of apex predators in their overwintering areas.

Acknowledgments Environment Canada through the Canadian Wildlife Service Latin America Program funded the collection of fish samples. Mercury analyses were funded by the Council for Economic Cooperation. For all their generous assistance in the field that made the field work in Mexico so successful, the authors thank Octavio Carretero and James Barr of Pronatura Veracruz, Manuel Gomez at Barra de Navidad, Armando Santiago at San Blas, and Jose Luis Rangel Salazar for all his help in Chiapas. The authors also thank Guy Savard and Della Bond for assistance in the lab. Lisa Pollock assisted with data analysis and preparation of tables and figures.

\section{References}

Anderson DW, Suchanek TH, Eagles-Smith CA, Cahill TM Jr (2008) Mercury residues and productivity in Osprey and grebes from a mine-dominated ecosystem. Ecol Appl 18:227-238

Bank MS, Chesney E, Shine JP, Waage A, Senn DB (2007) Mercury bioaccumulation and trophic transfer in sympatric snapper species from the Gulf of Mexico. Ecol Appl 17:2100-2110

Braune BM, Gaston AJ, Elliott KH, Provencher JF, Woo KJ, Chambellant M, Ferguson SH, Letcher RJ (2014) Organohalogen contaminants and total mercury in forage fish preyed upon 
by thick-billed murres in northern Hudson Bay. Mar Pollut Bull 78:258-266

Burnham KP, Anderson DR (2002) Model selection and multimodel inference: a practical information-theoretic approach, 2nd edn. Springer, New York

Choy ES, Gauthier M, Mallory ML, Smol JP, Douglas MSV, Lean D, Blais JM (2010) An isotopic investigation of mercury accumulation in terrestrial food webs adjacent to an Arctic seabird colony. Sci Total Environ 408:1858-1867

Clarke KR, Gorley RN (2006) Primer v5: user manual/tutorial. Primer-E, Plymouth

Davis JA, Greenfield BK, Ichikawa G, Stephenson M (2008) Mercury in sport fish from the Sacramento-San Joaquin Delta region, California, USA. Sci Tot Environ 391(1):66-75

Depew DC, Basu N, Burgess NM, Campbell LM, Evers DC, Grasman KA, Scheuhammer AM (2012) Derivation of screening benchmarks for dietary methylmercury exposure for the common loon (Gavia immer): rationale for use in ecological risk assessment. Environ Toxicol Chem 31:2399-2407

DesGranges JL, Rodrigue J, Tardif B, Laperle M (1998) Mercury accumulation and biomagnification in ospreys (Pandion haliaetus) in the James Bay and Hudson Bay regions of Quebec. Arch Environ Contam Toxicol 35:330-341

Dietz R, Sonne C, Basu N, Braune B, O'Hara T, Letcher RJ, Scheuhammer $\mathrm{T}$, Andersen $\mathrm{M}$, Andreasen $\mathrm{C}$, Andriashek $\mathrm{D}$, Asmund G, Aubail A, Baagoe H, Born EW, Chan HM, Dercocher AE, Grandjean P, Knott K, Kirkegaard M, Krev A, Lunn N, Messier F, Obbard M, Olsen MT, Ostertag S, Peacock E, Renzoni A, Riget FF, Utne Skaare J, Stern G, Stirling I, Taylor M, Wiig I, Wilson S, Aars J (2013) What are the toxicological effects of mercury in Arctic biota? Sci Tot Environ 443:775-790

Eagles-Smith CA, Ackerman JT, De La Cruz SE, Takekawa JY (2009) Mercury bioaccumulation and risk to three waterbird foraging guilds is influenced by foraging ecology and breeding stage. Environ Pollut 157:1993-2002

Elliott KH, Davis M, Elliott JE (2014) Equations for lipid normalization of carbon stable isotope ratios in aquatic bird eggs. PLoS One 9:e83597

Elliott JE, Levac J, Guigueno MF, Shaw DP, Wayland M, Morrissey CA, Elliott KH (2012) Factors influencing legacy pollutant accumulation in alpine osprey: biology, topography, or melting glaciers? Environ Sci Technol 46:9681-9689

Elliott JE, Machmer MM, Henny CJ, Wilson LK, Norstrom RJ (1998) Contaminants in ospreys from the Pacific Northwest: I. Trends and patterns in polychlorinated dibenzo-p-dioxins and-dibenzofurans in eggs and plasma. Arch Environ Contam Toxicol 35:620-631

Elliott JE, Machmer MM, Wilson LK, Henny CJ (2000) Contaminants in ospreys from the Pacific Northwest: II. Organochlorine pesticides, polychlorinated biphenyls, and mercury, 1991-1997. Arch Environ Contam Toxicol 38:93-106

Elliott JE, Morrissey CA, Henny CJ, Ruelas Inzunza E, Shaw P (2007) Satellite telemetry and prey sampling reveal contaminant sources to Pacific Northwest Ospreys. Ecol Appl 17:1223-1233

García-Hernández J, Cadena-Cárdenas L, Betancourt-Lozano M, García-De La Parra LM, García-Rico L, Márquez-Farías F (2007) Total mercury content found in edible tissues of top predator fish from the Gulf of California, Mexico. Toxicol Environ Chem 89:507-522

Grove RA, Henny CJ, Kaiser JL (2009) Osprey: worldwide sentinel species for assessing and monitoring environmental contamination in rivers, lakes, reservoirs, and estuaries. J Toxicol Environ Health 12:25-44

Guigeno MF, Elliott KH, Levac J, Wayland M, Elliott JE (2012) Differential exposure of alpine ospreys to mercury: melting glaciers, hydrology or deposition patterns? Environ Int 40:24-32
Harris ML, Elliott JE (2011) Polychlorinated biphenyls, dibenzo-pdioxins and dibenzofurans and polybrominated diphenyl ethers in birds. In Beyer WN, Meador J (eds) Environmental contaminants in wildlife-interpreting tissue concentrations. CRC Press, New York, NY, pp 471-522

Heinz GH, Hoffman DJ, Klimstra JD, Stebbins KR, Kondrad SL, Erwin CA (2009) Species differences in the sensitivity of avian embryos to methylmercury. Arch Environ Contam Toxicol 56:129-138

Henny CJ, Kaiser JL, Grove RA (2009) PCDDs, PCDFs, PCBs, OC pesticides and mercury in fish and osprey eggs from Willamette River, Oregon (1993, 2001 and 2006) with calculated biomagnification factors. Ecotoxicology 18:151-173

Hopkins WA, Hopkins LB, Unrine JM, Snodgrass J, Elliot JD (2007) Mercury concentrations in tissues of osprey from the Carolinas, USA. J Wildlife Manage 71:1819-1829

Hughes KD, Ewins PJ, Clark KE (1997). A comparison of mercury levels in feathers and eggs of osprey (Pandion haliaetus) in the North American Great Lakes. Arch Environ Con Tox 33: $441-452$

Kamman NC, Burgess NM, Driscoll T, Simonin HA, Goodale W, Linehan J, Scruton DA (2005) Mercury in freshwater fish of northeast North America-a geographic perspective based on fish tissue monitoring databases. Ecotoxicology 14:163-180

Logan JM, Jardine TD, Miller TJ, Bunn SE, Cunjak RA et al (2008) Lipid corrections in carbon and nitrogen stable isotope analyses: comparison of chemical extraction and modelling methods. J Anim Ecol 77:838-846. doi:10.1111/j.1365-2656.2008.01394.x

Malm O (1998) Gold mining as a source of mercury exposure in the Brazilian Amazon. Environ Res 77(2):73-78

Martell MS, Henny CJ, Nye PE, Solensky MJ (2001) Fall migration routes, timing, and wintering sites of North American Ospreys as determined by satellite telemetry. Condor 103(4):715-724

Martell MS, Bierregaard RO, Washburn BE, Elliott JE, Henny CJ, Kennedy RS, MacLeod I (2014) The spring migration of adult North American ospreys. J Rap Res 48:309-324

Mol JH, Ramlal JS, Lietar C, Verloo M (2001) Mercury contamination in freshwater, estuarine, and marine fishes in relation to small-scale gold mining in Suriname, South America. Environ Res Sect A 86:183-197

Neugebauer EA, San Cartier GL, Wakeford BJ (2000) Methods for the determination of metals in wildlife tissues using various atomic absorption spectrophotometry techniques. Technical Report Series No 337, National Wildlife Research Centre, Environment Canada, Ottawa, ON, Canada

Nriagu JO (1994) Mercury pollution from the past mining of gold and silver in the Americas. Sci Total Environ 149:167-181

Post DM (2002) Using stable isotopes to estimate trophic position: models, methods, and assumptions. Ecology 83:703-718

Ruelas-Inzunza J, Páez-Osuna F (2005) Mercury in fish and shark tissues from two coastal lagoons in the Gulf of California, Mexico. Bull Environ Contam Toxicol 74:294-300

SAS Instit (2000) SAS/STAT Users Guide: Statistics. Release 8. SAS Institute, Inc., Cary

Scheuhammer AM, Bond D (1991) Factors affecting the determination of total mercury in biological samples by continuous-flow cold vapor atomic-absorption spectrophotometry. Biol Trace Elem Res 31:119-129

Scheuhammer AM, Meyer MW, Sandheinrich MB, Murray MW (2007) Effects of environmental methylmercury on the health of wild birds, mammals and fish. Ambio 36:12-19

Scheuhammer AM, Basu N, Burgess NM, Elliott JE, Campbell GD, Wayland $M$ et al (2008) Relationships among mercury, selenium, and neurochemical parameters in common loons (Gavia immer) and bald eagles (Haliaeetus leucocephalus). Ecotoxicology 17:93-101 
Scheuhammer A, Basu N, Evers DC, Heinz GH, Sandhenrich MB, Bank MS (2012) Ecotoxicology of mercury in fish and wildlife: recent advances. In: Bank MS Toxicology, risk analysis, humans and policy. University of California Press, Oakland

Schuster PF, Krabbenhoft DP, Naftz DL, Cecil LD, Olson ML, Dewild JF, Susong DD, Green JR, Abbott ML (2002) Atmospheric mercury deposition during the last 270 years: a glacial ice core record of natural and anthropogenic sources. Environ Sci Technol 36:2303-2310

Shore RF, Pereira G, Walker LA, Thompson DR (2011) Mercury in nonmarine birds and mammals. In: Beyer WN, Meador JP (eds) Environmental contaminants in wildlife: interpreting tissue concentrations, 2nd edn. CRC, Boca Raton, pp 609-624

Streets DG, Zhang Q, Wu D (2009) Projection of global mercury emissions in 2050. Environ Sci Technol 43:2983-2988

Wang Q, Kim D, Dionysiou DD, Sorial GA, Timberlake D (2004) Sources and remediation for mercury contamination in aquatic systems: a literature review. Environ Poll 131:323-336
Weech SA, Scheuhammer AM, Elliott JE, Cheng KM (2004) Mercury in fish from the Pinchi Lake region, British Columbia, Canada. Environ Pollut 131:275-286

Weech SA, Scheuhammer AM, Elliott JE (2006) Mercury exposure and reproduction in fish-eating birds breeding in the Pinchi Lake Region, British Columbia, Canada. Environ Toxicol Chem 25:1433-1440

Wiener JG, Krabbenhoft DP, Heinz GH, Scheuhammer AM (2003) Ecotoxicology of mercury. In: Hoffman DJ, Rattner BA, Burton GA, Cairns J (eds) Handbook of ecotoxicology, 2nd edn. Lewis Publishers, CRC Press, Boca Raton, pp 409-463

Wyn B, Kidd KA, Burgess NM, Curry RA, Munkittrick KR (2010) Increasing mercury in yellow perch at a hotspot in Atlantic Canada, Kejimkujik National Park. Environ Sci Technol 44(23):9176-9181 